\title{
Men and the Suffrage ${ }^{1}$
}

\author{
Sigríður Dúna Kristmundsdóttir, Professor of Anthropology, University of \\ Iceland.
}

\begin{abstract}
Around the turn of the last century the suffrage was a crucial political issue in Europe and North America. Granting the disenfranchised groups, all women and a proportion of men, the suffrage would foreseeably have lasting effects on the structure of society and its gendered organization. Accordingly, the suffrage was hotly debated. Absent in this debate were the voices of disenfranchised men and this article asks why this was so. No research has been found on why these men did not fight for their suffrage while women's fight for their suffrage has been well researched. Within this context, the article examines the case of Iceland, in terms of issues such as the importance of urbanization, social change and culturally defined perceptions of men and women as social persons. It is argued that men did not have the same impetus as women to fight for their suffrage, and that if they had wanted to they were in certain respects disadvantaged compared to women. The gendered organization of society emerges as central in explaining why women fought for their suffrage and men did not, and why women's suffrage received more attention than men's general suffrage. As a case study, offering a microcosmic view of the subject in one social and cultural context, it allows for comparison with other like studies and with ongoing social processes
\end{abstract}

Keywords: suffrage; men; gendered organization of society.

\section{Introduction}

In the last decades of the $19^{\text {th }}$ century and well into the 1900 s, the suffrage was a passionately debated political issue in Europe and North America. Granting women and

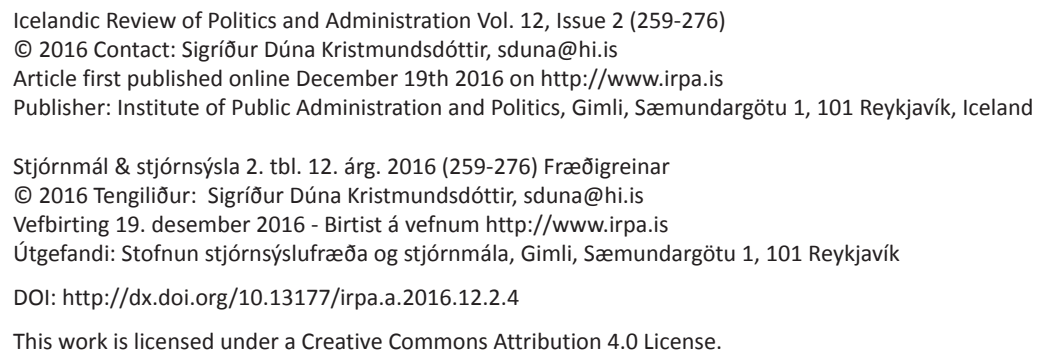


disenfranchised men the suffrage could foreseeably have lasting effects on the political structure of society, and opinions were accordingly divided. Women were on the march, demanding the suffrage for women, while disenfranchised men kept silent on the subject. That raises the central questions of this article: why did disenfranchised men not demand the suffrage? And why was there such difference between women and men in this respect?

No research focusing on men and the suffrage has been found (Gutman 1997; Nye 2005), and it is hoped that this article may help break new ground where this issue is concerned. Women's fight for their suffrage has been well researched and provides useful comparative material. The paper discusses women and the suffrage as an international movement but focuses on the case of Iceland. The ethnographic case study, understanding a particular social phenomenon in its historical and cultural context, is one of the working tools of anthropology. It emphasizes the importance of context and recommends comparison with other like case studies to allow a more general understanding of a particular social phenomenon. This article will contribute to such comparisons.

Anthropologists normally use qualitative research methods: interviews with social actors in the field and participant observation. When engaging with the past this method necessarily consists of finding the voices of actors in sources such as letters and printed material, and in understanding their social and cultural context from studying both primary and secondary sources (Kristmundsdóttir 2001). The primary sources available in this study are the voices of members of the Althing when debating the suffrage as recorded verbatim in Alpingistíðindi or Records of the Althing. Other primary sources are found in discussions of the suffrage in papers and periodicals published at the time as well as in other contemporary sources on Icelandic society and culture. My work on the Icelandic Women's Movement 1870-1990 (Kristmundsdóttir 1997), used here, is based on research of primary sources of this kind. Secondary sources include the work of historians who have researched the period and issues being dealt with, especially the work of Gunnar Karlsson, Professor Emeritus at the University of Iceland, who has researched democratic development in Iceland for decades. For statistical information Hagskinna: Icelandic Historical Statistics (Jónsson \& Magnússon 1997), an accumulation of statistical tables, is employed.

A number of theoretical perspectives are applied to the data. Social structuralism as developed in anthropology (e.g. Fortes 1970) is a basic theoretical premise as is the concept of gender. Gender is understood to be a symbolic construction based on the relationship between "sexed bodies, symbolic representations of female and male, and the actual behaviour of individual women and men "(Barnard \& Spencer 2002, 275). Gender is a dimension of social structure, and together these concepts create the gendered structure or organization of society that is central to this study. Social rights activism, such as campaigning for the suffrage, is a method to recreate social persons and hence the concept of the person is applied. In accordance with the social structuralist approach the person is defined as "... the microcosm of the social order, incorporating its distinctive principles of structure and norms of value" (Fortes 1987, 286). Harris 
(1989), developing the concept further, argues that the social person has three generally accepted abilities, that of action, that of judgment and sometimes that of the supernatural, all of which he or she can use to change their social personhood. Gender is a component of the person and Hearn's work on how men have traditionally not been seen to be gendered social persons (Hearn 2015) is employed. From these perspectives it is asked what role the gendered organization of society played in the different approaches of men and women to campaigning for the suffrage and what motives it afforded them or not to recreate themselves as social persons?

Further, Jónasdóttir's (1991) theory on the social organization of love is brought to bear on the material. Can this theoretical perspective further explain if and why men did not have the same motivation as women to fight for their suffrage and why women's suffrage received more attention than men's general suffrage? Does Ardener's (1975) perspective on dominant and muted social groups also help elucidate why disenfranchised men such as farm workers did not fight for their suffrage? Did their position in the social structure mute them? Other tenets of anthropological theory are applied, such as an understanding of essentialism as assuming "an unchanging, primordial ontology to what are the historically contingent products of human or other forms of agency" (Barnard \& Spencer 2002, 188). As such, essentialism repudiates the importance of human agency, not least that of persons to recreate themselves as social actors without regard for, or in opposition to, accepted norms and values. Such recreation of social personhood is central to social movements such as women's campaign for their suffrage (Kristmundsdóttir 1997).

Given the historical dimension of the subject, the paper starts by giving an outline of the development of the suffrage in Iceland and of the international campaign for women's suffrage in the late 1800s and early 1900s, of which the Icelandic case is a part. Then the underpinnings of Icelandic women's campaign for the suffrage is examined and what they reveal comparatively about disenfranchised men's silence on the subject. That is followed by a consideration of the social and economic position of disenfranchised men in Iceland at the time and the 40-year age limit in the 1915 suffrage law. Finally, answers to the central questions of the paper are advanced and the centrality of gender laid out.

\section{Historical background to the suffrage in Iceland}

In the years 1376-1380 Iceland entered into a formal relationship with the King of Denmark and after the dissolution of the Calmar Union, a confederation of the Nordic Kingdoms, in 1521, it became part of the Kingdom of Denmark. Iceland obtained sovereignty from Danish rule in 1918, but the formal relationship to the Danish King was not dissolved until 1944 when Iceland unilaterally declared itself a sovereign republic (Karlsson 2000). As suffrage rights are dependent on forms of government, Iceland's political relationship to Denmark was central in the evolution of suffrage rights in the country.

The first signs of suffrage in Iceland appeared in 1843. In the wake of the French 


\section{STJÓRNSÝSLA}

revolution in 1789, and the rise of nationalism in Europe, ideas about the rights of nations to self-determination began to spread. Icelanders, especially those resident in Copenhagen, welcomed these ideological developments and in the 1830s began to argue for Iceland's right to independence from Denmark. In 1837 they petitioned the King for an Icelandic consultative assembly, and in 1843 the King heeded their requests by issuing a decree granting Iceland such an assembly as he had other parts of his Kingdom. Though only consultative, the assembly was named Althing, with reference to Iceland's old legislative assembly, established in 930 (Karlsson 2008a). The decree, which stipulated who had the right of vote and the rules of eligibility to the new Althing, was the first suffrage legislation for Iceland. It limited suffrage rights to the top layer of society; property owners or those who met comparable economic requirements and had reached 25 years of age. It effectively extended to $2.2 \%$ of Iceland's population (ibid).

In 1857 the King issued a new decree about elections to the Althing, extending the suffrage by more specific requirements, such as paying taxes, holding a university degree or being a high-ranking public functionary (ibid). It took into account the fact that economic and social conditions in Iceland were different from those in Denmark, and effectively extended the suffrage to $8-10 \%$ of the population, over $90 \%$ of which were farmers (Thorarensen 2015; Karlsson 2008b). On the millennium landmark of Iceland's settlement in 1874 the King, as asked by the Althing, granted Iceland its first constitution, giving the Althing limited legislative powers. The requirements for the suffrage did not change, but since 1874 suffrage rights have been part of Iceland's constitutional law (Thorarensen 2015).

In the following decades the Althing debated how to change the constitution, in which the suffrage rights were included. Yet, until 1903, when amendments were made to the constitution, the requirements for the suffrage remained unchanged (Karlsson 2008b). Hence, for almost half a century, from 1857 to 1903, suffrage rights in Iceland did not evolve, and there was no change in either the percentage of the population that held the right to vote or in the composition of the group that could vote and stand for election. The suffrage requirements effectively excluded women, as, with few exceptions, women were not owners of property, did not pay taxes, were excluded from higher education and were never appointed public functionaries. They also excluded a sizeable chunk of the male population in the country.

The idea of a general or a more extended suffrage had not taken hold in Europe in the late $19^{\text {th }}$ century. In 1884 , the suffrage extended to $15 \%$ of the population of Denmark, $11.5 \%$ of the population of England and around $26 \%$ of the population of France, where it was highest, with Germany and Switzerland following close behind (Karlsson 2002). In all instances the suffrage applied to men only. It was assumed that those who were economically dependent on others did not possess the necessary independence to take part in the governing of a country, which the suffrage entailed. These ideas have been traced to Aristotle (Thorarensen 2015) but may simply have been the accepted interpretation of Aristotle at the time. In any case the idea that only men of means or economically independent men should hold the suffrage had decisive influ- 
ence on the evolution of the suffrage in the $19^{\text {th }}$ century and into the early 1900 s. The idea of the suffrage as a human right, as opposed to a specific right of certain groups, was only slowly gaining ground.

The 1903 amendments to Iceland's constitution extended the suffrage to all men 25 years of age and over who were financially independent, paid tax and had a clean record (Stjórnarskéa 1903). The Althing reasoned that since new occupational categories had emerged since the constitution of 1874 , the existing suffrage law was too narrow (Alpingistífindi 1903). Besides, the number of farmers was diminishing. By 1910, when the Althing was yet again debating the constitution and the suffrage, men over 25 years of age were almost $25 \%$ of the population. Of these, $15 \%$ had, by the constitutional amendments of 1903, gained the suffrage, whereas $10 \%$ had not. If men over 25 years of age are considered as a group, it emerges that around $60 \%$ of them had been enfranchised, whereas 40\% had not (Hagskinna 1997, 125, 877). These men (hereafter named the $40 \%$ group) finally received the suffrage in 1915 as did women, albeit with a 40-year age limit.

\section{Women and the suffrage}

Feminism as a political ideology has a long history. In accordance with changing ideas and social conditions through the centuries, feminists emphasised different aspects of women's emancipation at different times; women's right to be educated being a relatively constant one. In the wake of the French Revolution in 1789, civil rights, such as the suffrage, became a major concern, and by the late $19^{\text {th }}$ century women's suffrage had become a pivotal concern of feminist activists. This was a time of increased emphasis on the nation state and nation building, and independence movements emerged among peoples that were subsumed within larger states and did not enjoy constitutional rights (Offen 2000).

In Europe and North America it was also a time of changing social and economic conditions, involving new modes of production and growing urbanization. Women, single and married, moved in increasing numbers to the growing urban areas and found that there their social position changed in accordance with the new urban social organisation, if not in terms of culturally entrenched ideas about who they were as social persons. In such a situation women's civil rights, and especially the suffrage, came to the fore as being of vital importance in the recreation of women as social persons. The franchise would enable women to become valid actors in the political arena and enable them to have their say in public decision-making and thus influence the structure and values of the society in which they lived. It would also make them formally equal to men in the central political arena of society (Offen 2000; Kristmundsdóttir 1997; Erlendsdóttir 1993).

As the $19^{\text {th }}$ century progressed, a number of societies working towards obtaining the suffrage for women emerged and subsequently united into suffrage movements. Three such movements were founded in the Nordic countries in the 1880s, and in 1890 suffrage societies in North America united as the National American Women's Suffrage Associa- 


\section{STJÓRNSÝSLA}

tion. In 1897 the National Union of Women's Suffrage Societies was founded in England, and in 1903 a more militant offspring of that movement, Women's Social and Political Union, emerged under the leadership of Emmeline Pankhurst. In 1909 French activists established the French Union for Women's Suffrage, and at the time the suffrage encompassed, and in a sense became a symbol for, women's emancipation generally. Activists spoke publicly and published on the issue, petitioned national assemblies, and the more militant such as the followers of Emmeline Pankhurst, used unconventional methods, which at times landed them in jail (Offen 2000; Bolt 1993).

The idea that women should enjoy the same civil rights as men was by no means new (see e.g. Wollstonecraft 1792) but never before had it been campaigned for as forcefully and by as many. In this, the improved education of women, freedom of speech and urbanisation were instrumental. It was also not only feminist women that campaigned for women's suffrage. John Stuart Mill, who in 1869 published his seminal work The Subjection of Women, argued two years previously in the British Parliament that women deserved the right to vote. He was greeted by laughter in the Commons, but also by some support, and by the end of the century several men's societies for women's suffrage were founded (Offen 2000; Bolt 1993).

The issue of women's suffrage was a serious one. It would upset the gendered organization of society by allowing women, defined in terms of the domestic sphere, to become valid actors in the public sphere, by which men were traditionally defined (Kristmundsdóttir 1998). Granting women the suffrage would radically change their social personhood and consequently that of men, who could no longer be deemed exclusively suitable to govern. That would, in turn, have far-reaching effects the position of men in both the domestic and public spheres, where women could be expected to demand equal rights to men. Women's suffrage was in a way a Trojan horse sent into the bastion of male power and supremacy and it was, not surprisingly, hotly debated.

The emergence of feminist activities in Iceland fits well within the context of these events. Since the 1830s, Icelanders had been arguing for the right to become an independent nation state, as is outlined in the chapter on the development of the suffrage in Iceland above. Women rights activists were on the move. The first school for women was established in 1874, followed by other schools for women around the country. Subsequently Icelandic women became better educated. The first women's society campaigning for the rights of all women was established in 1894, followed by The Women's Rights Society in 1907 which focused on women's suffrage (Kristmundsdóttir 2006, 1997; Erlendsdóttir 1993; Styrkársdóttir 1982)

At the end of the 19th century Icelandic society changed radically, with new methods of production and growing urbanisation. Women were moving from the countryside, where farming was the mainstay of production, to the growing urban areas around the coast, fuelled by the mechanization of fishing in the rich fishing grounds around the island. In urban centres, small and few though they were, women had better access to ideas emanating from abroad, and to each other (Kristmundsdóttir 1997). The main elements listed by Offen (2000) as underlying the suffrage movement - ideas of national 
independence, better education for women and growing urbanization - were in place in Iceland.

As noted above, $40 \%$ of Icelandic men over 25 years of age did not enjoy the suffrage until 1915, when they were granted it along with all women. There is no evidence that this group of men campaigned for their suffrage in any concerted manner. They seem to have been passive towards the issue, or muted in Ardener's (1975) understanding of muted social groups as not having a valid or audible voice in the public sphere of society.

\section{Underpinnings}

Struggles for civil rights have their roots in perceived injustices and are shaped by social and cultural conditions. What were the underpinnings or contextual causes of Icelandic women's fight for the suffrage? And what do they say about men's muteness where their suffrage is concerned?

\subsection{Independence}

As noted above, Icelandic women's fight for the suffrage was concomitant with Iceland's struggle to gain independence from Denmark. The Althing debated changes to the constitution and the eventual sovereignty of Iceland repeatedly and simultaneously with suffrage rights, as they were determined in the constitution. Hence the development of the suffrage and Iceland's political relationship to Denmark went hand in hand.

"Independence" and "sovereignty" were dominant and pervasive concepts in Icelandic discourse during Iceland's struggle to dissolve its political relationship to Denmark. There are indications that the suffragists conceptually combined Iceland's right to selfdetermination and independence with rights of women to self-determination and a valid voice in society, of which the suffrage was an important element. Or, as the daughter of one of the suffragists wrote in her 1929 exposition on the struggle, "[the struggle for the suffrage] grew side by side with the struggle for independence and almost at the same time Iceland and her daughters became free" (Valdimarsdóttir 1929, 11).

There is no ideological reason why the $40 \%$ group of disenfranchised men should not have been fuelled by Iceland's struggle for independence as the women seem to some extent to have been. Iceland's struggle for independence from Denmark was primarily led and fought by men (e.g. Hálfdanarson 2001). In other words, it was a masculine activity, and so the men in the $40 \%$ group should not, on the basis of their gender, have been prevented from aligning with other men in the independence struggle. For that they needed the suffrage, and yet they did not ask for it, leaving it to the $60 \%$ of their gender group who had the suffrage to do what was needed.

\subsection{Gender groups}

As all women were disenfranchised, they could fight for their suffrage as a gender group, and, as they did, on the basis of their gender-defined cultural capital. Women should be given the vote, they argued, because, being women, they were different from men and 
their lives demanded different capabilities and afforded different experiences. Consequently, women saw things differently from men and their viewpoints were needed in all public affairs. Or, as Bríet Bjarnhéðinsdóttir, one of the most active suffragists, argued in 1907 in her paper Kvennabladid: women should be given the suffrage because society needed their loving mother's care in all its affairs, not least when decisions were made about the old, poor and infirm, and always when virtue and moral excellence were required (Bjarnhéðinsdóttir 1907). Similar opinions were expressed in the Althing, where members would praise these "feminine" qualities (e.g. Alpingistidindi 1911).

This line of argumentation is based on deeply ingrained cultural values of Icelandic society; women's "natural" roles are those of mothers and carers, and their "natural" place in society is in the home (Kristmundsdóttir 1998). It is an essentialist view of women's place in society and not all suffragists subscribed to it, but it prevailed and in the end won women their rights. Not only were the suffragists not always in agreement, even on such basic issues as the ideological grounds on which to fight for the vote, but not all women thought that women should be granted the suffrage (Krismundsdóttir 2006). Yet this did not prevent the suffragists from arguing for, and fighting for, women's suffrage rights in the name of all women.

Not so for the $40 \%$ group of disenfranchised men. The option of arguing for their suffrage in terms of gender was not open to them. First, $60 \%$ of men already held the suffrage and so, their gender group, unlike that of women, was divided and could not provide a basis from which to proceed. Second, it is unlikely men saw themselves as a gender group. Occupation, family or economic and social position, not gender, were the important indicators of who they were and how they thought of themselves. It has been argued that men did not emerge as gendered subjects until the last decades of the $20^{\text {th }}$ century, and then in relation to feminist, racial and sexual struggles. Until then they were not a gender group; they were the norm in terms of which women were defined (Hearn 2015). If men were perceived as a gender group, the $40 \%$ group of disenfranchised men could have argued that since $60 \%$ of men already held the vote they as men should be given it too. They did not.

\subsection{Inspiration and sisterhood from abroad}

The women in Iceland who fought for the suffrage were inspired by ideas from the neighbouring countries where women were actively engaged in promoting women's suffrage as outlined above. The Women's Rights Society in Iceland had ties with sister societies abroad and was a member of the International Woman Suffrage Alliance, which held conferences where suffragists, including Icelandic representatives, met and supported each other in the struggle (Kristmundsdóttir 1997; Erlendsdóttir 1993; Styrkársdóttir 1982)

No such luck for the $40 \%$ group of disenfranchised Icelandic men. Ideas about extending men's suffrage, or about the right of all men to hold the suffrage without limitations, were, from time to time, debated in the Althing and written about in the papers. Yet nothing happened in this respect until 1915, when they were granted the suffrage, along with all women. It is of note that in what discussion on their suffrage there was, it 
was not conducted with reference to their gender, as was the case with women's suffrage, but rather in terms of their social and economic position, and occasionally in terms of human rights (Alpingistidindi 1901, 1903, 1907a).

Women's suffrage, very much thought of in terms of gender, was given much more attention than that of men, and not only in Iceland. No men's societies or men's movements arguing for the right of all men to be enfranchised seem to have existed. Societies of men, like the Men's League for Women Suffrage, founded in Great Britain in 1907, can be found, as can men's societies against women's suffrage, but no men's societies for men's general suffrage (Simkin 2015). Compared to women, the men in the $40 \%$ group were disadvantaged as in their case there were no international or even Nordic societies to inspire or support them if they had chosen to fight for their suffrage. There was sisterhood in the field but not brotherhood.

\subsection{Social change and social personhood}

Icelandic women's fight for the suffrage was deeply rooted in the changes taking place in Icelandic society. The mechanization of the fisheries in the early 1900s and the consequent growing of small urban centres around the coast were instrumental in that respect. People were moving from the countryside into the growing urban areas, away from the social organization and subsistence economy of the farming society and into a new fledgling industrial and urban social order. The women who fought for the suffrage and founded the women's rights societies mostly lived in those new urban centres and hence experienced this shift most profoundly (Kristmundsdóttir 1997).

In the new urban social order, the division between the domestic and public spheres of society, that of the home and that of production and public affairs, became more pronounced. Women found themselves confined to a larger degree to the domestic sphere, without the tools to have a valid voice in the new and rapidly growing public sphere. Women's social environment, the structure of the society in which they lived, was changing, but not the culturally determined ideas about their role and place in society as mothers and housewives, defined by the domestic sphere. In this situation women sought to recreate themselves as social persons by demanding rights, such as education and the suffrage, that would allow them to become valid actors in the public sphere. Hence, the social change that was taking place was instrumental in prompting Icelandic women to fight for their suffrage (Kristmundsdóttir 1997).

Of course social change also affected the $40 \%$ group of men: it enabled them to move away from the countryside to the fledgling urban areas where they had new working opportunities. But their need to reinvent themselves as social persons was not like that of women. They, being men, were already identified with the public sphere of society, even if they could not vote. The position of provider and head of household was open to them and their place as men in a male predicated society was not threatened by the fact that they did not have the vote. Also, they could obtain the suffrage by becoming wealthy enough; an option closed to women. However poor they were, they were still men in a men's society and their need to reinvent themselves as social persons was 
either non-existent or nowhere as strong as that of women. In short, the $40 \%$ group of men did not have the same underpinnings as women in their fight for the suffrage. Of concern in their case was their economic and social position.

\section{Economic and social factors}

\subsection{The composition of the $40 \%$ group of disenfranchised men}

Who were the men in the $40 \%$ group? In the absence of statistical information, we have to look at the requirements the Constitution of 1903 laid down for the suffrage and deduce from there who these men were. The constitution stipulated that men who had reached 25 years of age and were farmers who paid taxes, or if they were not farmers had paid a certain amount in extra municipal tax, were public officials or held a university level degree, had the right to vote in elections to the Althing. Twice it is stipulated in the text that no man who is dependent on others as a labourer or a household servant can have the right to vote (Stjórnarskera 1903). So the $40 \%$ of men over 25 who received the vote in 1915 must have been farm labourers, employed in some capacity by others or self-employed men too poor to pay the required taxes. As almost $60 \%$ of the population were in engaged in agriculture in 1901, it seems likely that a good proportion of these men were farm labourers (Hagskinna 1997, 217).

\subsection{Dependency}

The issue of dependency is an important one. In the $19^{\text {th }}$ century, when the suffrage was slowly extended to men of substance, it was assumed that those who were economically dependent on others did not possess the necessary independence to take part in the governing of a country (Thorarensen 2015). Hence, dependency seems to have been instrumental in denying the $40 \%$ group of men the suffrage. However, not all of the men in that group were dependent on others for their livelihood. Some were independent farmers or entrepreneurs in urban areas and even if they could provide for themselves and their families they were too poor to pay the taxes stipulated by the 1903 constitutional law.

This issue was discussed in the Althing and in the papers. In 1894 the paper Austri argued that financially independent men in urban areas (kaupstaðaborgarar) and farmers without the necessary requirement of ownership of land (purrabúðarmenn), as well as some urban workers (húsmenn), should be given the suffrage. The paper contended that these men were no less informed than those who already enjoyed the suffrage. It further pointed out that with rights come duties and that without the suffrage rights these men would also not have the attendant duties. In 1902 Isafold argued along the same lines, and in 1906 Dagfari maintained that the suffrage should not be contingent on men's economic position. The paper worried that in this matter Iceland is lagging behind other European countries.

In 1907 a bill was tabled in the Althing proposing that economically independent men who were too poor to pay the required taxes should be given the suffrage. The arguments advanced against this proposal were that it left out farm workers and some 
farmers who would not be receiving the suffrage concomitantly. In a society that perceived itself as a farming society this was thought to be a grave injustice. The bill was not passed (Alpingistídindi 1907b).

\subsection{Class?}

Dependency is hence not the only criteria that could prevent men from receiving the suffrage. Should we perhaps be looking at class? In the above discussions in the Althing the word class (stjett) was used when comparing farmworkers to financially independent men, especially men of no fixed abode, the latter being found much less deserving of the suffrage than "honest" farmworkers (Alpingistidindi 1907b). If we define class as a relationship to the means of production (Barnard \& Spencer 2002), the constitution of 1903, and the constitutional acts preceding it, appear to be class oriented. The determining factor of eligibility for the vote is property and the ability of the men to earn enough to contribute to the common good by paying taxes, both of which depend on their relationship to the means of production.

Anthropologist working in tribal and peasant societies have, however, often found the concept of class of limited use as it does not give due recognition to vertical links across apparent class boundaries, such as those of kinship, religion, gender, honour and self-identification with a community (Barnard \& Spencer 2002). This is evident in the case of women and the suffrage in Iceland. There women fought for the suffrage in terms of gender and never suggested that the suffrage should be given to only some women according to their class or economic standing; it should be given to all women. Besides, the large majority of women had little wealth of their own and most were dependent on men for their livelihood. They had few educational opportunities to qualify them for skilled jobs, and in menial jobs they were paid less than men who did the same work. Female farmworkers were paid less than their male co-workers because they were women, not because they had a different relationship to the means of production. In their case gender and sometimes kinship were more decisive than class. If the same is true for men, especially farmworkers, it raises the question of what the defining elements were where they were concerned.

\subsection{The domain of the farm and the case of the male farmworker}

In 1901 , when the constitution of 1903 was being drafted, about $60 \%$ of the population was employed in agriculture (Hagskinna 1997, 217). Farming had been the mainstay of the population for centuries, and the social and cultural values of the farming society informed the social organization and norms of the wider society. In Iceland, property holding and tax-paying farmers had, for decades, held by far the largest percentage of the vote. It has been suggested that the Althing was, in effect, primarily a mouthpiece for farmers (Karlsson 2000). When the suffrage in the 1903 constitution was being decided upon in the Althing, farmers had critical influence.

A defining feature of the farming society was that farms were not grouped together into villages, but were spaced apart, making the farm into a domain of its own where the 
public and private spheres merged to an extent. In the domain of the farm the farmer had ultimate authority, sharing it with his wife where household matters were concerned. Farmworkers were thus not only dependent on their employer for their livelihood, but also on their good opinion, and were subject to their authority in everyday life without recourse for complaints. Issues of payment were considered a private matter between the worker and the farmer, and the farmer was considered to have the right to demand absolute loyalty from his workers (Karlsson 2009a).

In this situation farmworkers had a closer identifying relationship with their employers, the community of the farm, and the farming society, than they had with their class. Honour was also at stake, as it was important for both the farmer and his workers to honour their relationship and be seen to do so. In their case, the vertical social concomitants of the fundamental relationships in the domain of the farm are a defining feature. It is suggested that the reason why male farmworkers were not enfranchised in the 1903 constitution was not because of class or wealth, but because of their close relationship to their primary social unit, the farm, and the demands it made on their loyalty to the farmer. Besides, giving the vote to male farmworkers could have multiplied the votes of farmers with many workers, as workers might not have dared to vote differently from their employer (Karlsson 2002). So class cannot be seen to have barred male farmworkers from receiving the vote in 1903 , but rather the vertical dependency of their relationships in the domain of the farm.

\section{The $\mathbf{4 0}$-year age limit in the $\mathbf{1 9 1 5}$ suffrage law}

In the first decades of the $20^{\text {th }}$ century, the idea that the suffrage should be given to all men and women above a certain age and with a clean record gathered support in the Althing (Alpingistídindi 1907b). Some of the papers backed this view (Fjódólfur 1907, Ingólfur 1909, Isafold 1911). A general suffrage was "in the air", as one member of the Althing asserted (Alpingistidindi 1907b). And so it was as the 40\% group of men, and all women, were given the suffrage in the 1915 constitution.

In that constitution, the age limit for the two, until then, disenfranchised groups was set at 40 years of age, to be lowered by a year each year so that everyone over 25 years of age would be enfranchised by 1930 (Stjórnarskrá 1915). This was a peculiarity not found in comparable legislation in the other Nordic countries. "A slap in the face of women" fumed suffragist Bríet Bjarnhéðinsdóttir (Bjarnhéðisdóttir 1913, 65). As regards men, this age limit continued to divide them into two groups: the men in the $60 \%$ group, who could vote at age 25 , and the men in the $40 \%$ group, who had to reach 40 years of age before they could use their suffrage.

When the Althing was drafting the 1915 constitution, various arguments against extending the suffrage to the existing 25 -year age limit were voiced. One was that it would allow for such a large influx of voters that the political system, and hence society, would be destabilized. Some members thought that such a change might amount to a revolution. A related argument was that the power of those who until then had held the vote - farmers and other taxpayers - would diminish considerably, and was that fair? It was 


\section{STJÓRNSÝSLA}

also mentioned that extending the vote to such a degree was not necessary as unanimous demands for its extension had not been put forward (Alpingistídindi 1911). Quite right, disenfranchised men had not demanded the vote, nor had all women, though the suffragists claimed it in the name of all women. At the heart of these arguments is the governing elite's fear of losing their unchallenged political power and position in society. The 40-year age limit ensured that political power would be devolved more slowly than otherwise.

But why was the age of 40 chosen by the Althing, rather than any other? Apart from the above, the records of the Althing do not tell. Men's suffrage was not discussed in terms of gender, but in terms of property and paying tax to the community, and it is clear that economic and social factors were most important where they were concerned (e.g. Alpingistidindi 2011). Although voices to the contrary could be heard in the Althing (ibid), the 40-year age limit may be seen to reflect on the disenfranchised men's perceived lack of social and financial independence. That would be in line with the accepted understanding of Aristotle's ideas, noted earlier.

Such considerations could not, however, be the case with women, as most women were not socially and economically independent anyway, and were not seen as such, although they contributed to the household economy. They fought for the suffrage as a gendered group and, as their suffrage was discussed in the Althing and elsewhere in terms of gender, it seems more pertinent to examine the 40-year age limit in terms of gender where they are concerned. Also, the number of women voters would be more than double that of new male voters and hence more threatening to vested political interests. It seems that the 40-year age limit may have had more to do with them than with the disenfranchised men.

To some members of the Althing it was of concern that women occupied by the duties of motherhood and caring for the family could not be expected to perform the duties the suffrage entailed (Alpingistífindi 2011). Would men perhaps lose the loving care of women in the home - their love power as will be discussed below - if they were expected to participate in public affairs? Were they capable of crossing the line from the domestic sphere, where no important decisions for the common good were made, into the public sphere, where national interests were at stake? These concerns were in accordance with the basic values of Icelandic society regarding the important role of women as mothers and carers of families. Granting the suffrage to women and to the $40 \%$ group of men, the 40-year age limit can be seen as a compromise, ensuring both the slow devolution of political power and the participation of fertile women in the political arena.

\section{Why disenfranchised men did not campaign for their suffrage?}

The $40 \%$ group of disenfranchised men can be divided into two groups: farmworkers and independent men often living in urban areas but too poor to pay the required taxes. It has emerged that the dependency of farmworkers, economic and vertical, can explain why they did not campaign for their suffrage. If they had, they would have gone 
against the social organization of the farming society on which they relied, and they were, accordingly, muted as a social group. That was not the case with the economically independent, if poor, men living in the small urban centres around the coast in growing numbers. Between 1901 and 1910 the percentage of the population employed in agriculture sank by 15\% (Hagskinna 1997, 217), so their numbers must have been growing. Why did they not campaign for their suffrage like the women who lived in these urban centres and were economically dependent on men?

The social change brought about by urbanization was an important element in inspiring women to attempt to recreate themselves as social persons. This they did by demanding the suffrage along with other rights, such as the right to education (Kristmundsdottir 1997; Erlendsdóttir 1993). Instead of campaigning for such rights men's efforts went into founding trade- and labour unions: the trade union of printers being the first one founded in 1887, followed by Dagsbrin, the union of workers, in 1896. This activity is consistent with the importance of social and economic factors in defining men's social personhood. In 1908, a demand for a general suffrage appears for the first time in the policy statement of the Alliance of Labour Unions or five years before the Althing reached an agreement on the suffrage. The Alliance supported the suffrage but central to its work were pressing issues such as the right to labour contracts, delimited working hours, improved conditions in the working place, wages and workers right to strike. (Friðriksson 2007; Hannibalsson 2016). Poor urban men's recreation of their social personhood hence centred on economic rights rather than rights such as the suffrage. It should also be remembered that by becoming prosperous enough men would automatically be granted the suffrage, an option closed to women.

It has also emerged that had these poor urban disenfranchised men wished to fight for their suffrage, they were in certain respects disadvantaged compared to women. They could not fight for their suffrage as a gender group since $60 \%$ of men already had the suffrage. As has been demonstrated above, men's general suffrage was discussed from time to time in the papers and in the Althing, and then in terms of their social and economic position. Men were not perceived as a gender group, as is argued above, and that is consistent with the fact that no societies for men's suffrage have been found to have existed. Nor could these disenfranchised men receive backing and inspiration from abroad, as women did, had they wished to fight for their suffrage. The idea of national independence did not translate for them into demanding their suffrage, as it did for women, but rather into demanding economic rights furthering their independence as earning social persons. They were men in a male predicated society and their personhood was already cut out for them in terms of the social and economic order in which they lived. From that point of view men would also not have had the same motivation to fight for their suffrage as women did.

\section{The centrality of gender}

Internationally, women's suffrage received much more attention than men's general suffrage. It was discussed and debated in parliaments and in the papers across northern 
Europe and North America, women's suffrage-societies were formed, international alliances of such societies founded and the suffragists themselves were vocal and visible (Offfen 2000; Bolt 1993). Why did women's suffrage invite this attention while men's general suffrage did not?

It is argued that giving women the suffrage was a more serious matter than men's general suffrage because it would mean transposing women formally onto the same level as men in the political arena and away from the domestic sphere, which defined them as social persons. It would, in short, give women a social personhood more akin to that of men and upset the long-established and ingrained gender boundaries of society. Men's general suffrage would not. It would change the economic definitions by which men were seen fit to govern, but not the gender boundaries on which society relied for many of its functions.

It has been maintained that the political implications of the social organization of love are fundamental to the functioning of patriarchal society (Jónasdóttir 1991). The love relationship institutionalized by heterosexual marriage, and based on gender, has transformative powers; it creates new people, the children born in the relationship, and recreates the social personhood of the men and women concerned. While love refers to mutual attraction and erotic pleasure, it also involves care and responsibilities, which, in the home, mostly devolve on women. In this respect, women's love power can be seen as comparable to the working power women and men sell on the labour market. Yet, in accordance with culturally determined ideas about women's role in society, women give generously of their love power in their love relationships. That leaves men free to pursue their goals in the public sphere, which, in turn, has determining influence on the gendered inequality of society. In this respect, the love relationship is a fundamental political relationship (Jónasdóttir 1991).

If this perspective is applied to the suffrage debates around the turn of the last century, it sheds light on why women's suffrage was so passionately debated while men's general suffrage was not. By giving women the suffrage it may reasonably have been feared that men would lose women's love power in the domestic sphere as women would expend energy and care by taking on responsibilities in the public sphere. That would mean they would have less time and energy to take care of the home, their men and their children. Such concerns were indeed voiced in the Althing (e.g.Alpingistidindi 1911).

Married or cohabiting men, enfranchised or not, could reap the benefits of women's love power in the domestic sphere and that may have contributed to the disenfranchised men's lack of interest in the suffrage - both their own and that of women. Marriage was important for their social personhood but the suffrage had nothing to do with their ability to marry. Similarly, women's love power can contribute to the explanation of why there seems to have been little general interest in male suffrage. As men did not possess love power to the same degree as women, giving men the suffrage presented a much smaller risk to the gendered organization of society than giving women the suffrage. Hence the disenfranchised men were side-lined and muted in the debate about the suffrage. 
As noted earlier women's fight for the suffrage has been widely researched in the social sciences, whereas men and the suffrage have, to this day, received little if any focused attention. We still seem to think of the suffrage as a women's issue. In a recent book on masculinities and politics, for instance, suffrage is indexed as "suffrage rights, women's" (Dudnik et al 2004, 324). Another, on the history of white people, does not index suffrage, but provides "voting rights" and then specifies "for women" and "for immigrants" (Painter 2010, 495). While that may demonstrate how the past still informs the social sciences, "the past in the present" as it were, it also points to the centrality of gender where the suffrage is concerned. The different levels of attention paid to men's and women's suffrage in the early 1900s point in the same direction, as do the explanations advanced above for why women and not men fought for their suffrage. Gender, and its various ramifications in the organization of society, emerges as a basic element when considering the suffrage and the fight, or the lack of such a fight, to achieve it.

\section{Concluding remarks}

It is hoped that this article contributes to breaking ground in research on the understudied subject of men's general suffrage and the reasons why women, and not men, campaigned for their suffrage. The examination touches upon basic issues in the social sciences, such as the gendered organization of society, the importance of urbanization, social change and the perception of men and women as social persons.

The ethnographic case of the suffrage in Iceland is examined as one of many suffrage campaigns that took place in Europe and North America at the time. As with all ethnographic cases, it invites comparison to other like cases. This is based on the premise that the social and cultural context of each case is important for its understanding and for facilitating cross-cultural comparisons, allowing for broader and more general conclusions about a particular social phenomenon.

The case of Iceland shows that due to various social and cultural factors such as being divided into two groups based on their economic and social position, being able to gain the suffrage by becoming prosperous enough, having access to women's love power regardless of the suffrage and being men in a male predicated society, men did not have the same motivation as women to recreate themselves as social persons. It also shows that had they wanted to they were in certain respects disadvantaged compared to women.

The suffrage as a human right is not gendered but the political organization of society is, and gender emerges as central in explaining why women fought for their suffrage and men did not, and why women's suffrage received much more attention than that of men. Women's suffrage threatened the long established and fundamental gendered organization of society, whereas men's general suffrage did not, and was, accordingly, a lesser hazard for the functioning of society.

This examination of one social rights campaign - that of the suffrage - also invites comparison with other such campaigns like that of gay rights allowing people to become valid social persons regardless of their sexual orientation. Finally, as the struggle for 


\section{STJÓRNSÝSLA}

gender equality is an on-going process, the issues dealt with here are currently relevant, as is their examination in the social sciences.

\section{Notes}

1 This paper was first presented at the conference Power and Democracy a Hundred Years Later at the University of Iceland June 18, 2015.

\section{References}

\section{Alpingistióindi}

1901 C-deild. Frumvarp til stjórnskipurnarlaga, 301-309.

1903 A-deild. Breyting á stjórnarskránni, 43-120.

1907a B-deild. Stjónarskérarbreyting, 2750-2756.

1907b B-deild. Almennur kosningarrjettur, 2169-2175.

1911 B-deild. Stjórnskipurnarlög, 905-1064.

Anna G. Jónasdóttir (1991). Love Power and Political Interests, Kumla, Örebro Sudies 7.

Auður Styrkársdóttir (1982). Kvennaframboðin 1908-1926. Reykjavík: Félagsvísindadeild Háskóla Íslands og Örn \& Örlygur.

Ardener, S. (ed.) (1975). Perceiving Women. London: J.M. Dent and Sons.

Barnard, A. and Spencer, J. eds. (2002). Encyclopaedia of Social and Cultural Anthropology. New York: Routledge.

Björg Thorarensen (2015). Sjórnskipunarréttur. Undistöđur og handhafar rikisvalds. Reykjavík: Bókaútgáfan Codex.

Bolt, C. (1993). The Women's Movements in the United States and Britain from the 1790's to the 1920's. Harvester Wheatsheaf. Amherst: University of Massachusetts Press.

Bríet Bjarnhéðinsdóttir (1907). "Kosningaréttarfélag", Kvennablaðid, 23. janúar, 2-3.

Bríet Bjarnhéðinsdóttir (1913). "Alpingi 1913 og stjórnarskrármálið”. Kvennabladid, 30. sept, 19. ár, no 9, 65.

Dudnik, S., Hageman, K. and J. Tosh (eds.) (2004). Masculinities in Politics and War. Gendering Modern History. Manchester University Press.

Fortes, M. (1970). Time and Social Structure and Other Essays. London: The Athlone Press, Univeristy of London.

Fortes, M (1987). „The Concept of the Person“, in Goody J. (ed.), Religion, Morality and the Person: Essays on Tallensi Religion (pp. 247-286). Cambridge: Cambridge University Press.

Guðmundur Hálfdanarson (2001). Íslenska pjóđríkið - uppruni og endimörk. Reykjavík: Hið íslenska bókmenntafélag, ReykjavíkurAkademían.

Gunnar Karlsson (2000). Íslandssaga i stuttu máli. Reykjavík: Mál og menning.

Gunnar Karlsson (2002). „Hvers vegna átti lýðræðið erfitt uppdráttar á 19.öld? Hvers vegna vildu menn takmarka kosningarétt við eigna- og menntamenn?" Vísindavefur Háskóla Íslands, https: visindavefur. hi.is/svar.php?id=2014, downloaded 13.2. 2015.

Gunnar Karlsson (2008a)."Stofnun Alpingis“ in S. Líndal and P. H. Árnason (eds.), Saga Íslands IX (p.p. 251-259). Reykjavík: Hið íslenska bókmenntafélag, Sögufélag.

Gunnar Karlsson (2008b)."Alpingiskosningar" in S. Líndal and P. H. Árnason (eds.), Saga Íslands IX, Reykjavík (p.p. 319-325). Reykjavik: Hið íslenska bókmenntafélag, Sögufélag.

Gunnar Karlsson (2009). „Verkalýðshreyfing“, in S. Líndal and P.H. Árnason (eds)., Saga Íslands X (134144).Reykjavík: Hið íslenska bókmenntafélag, Sögufélag.

Gutmann, M.C. (1997). "Trafficking in men: The anthropology of masculinity", Annual Review of Anthropology 26, 385-409. 


\section{STJÓRNSÝSLA}

Hagskinna. Icelandic Historical Statistics, G. Jónsson and M. S. Magnússon (eds.) (1997). Reykjavík: Hagstofa Íslands.

Harris, G. G. (1989). „Concepts of Individual, Self and Person in Description and Analysis“, American Anthropologist 91 (3), 599-612.

Hearn, Jeff (2015). Men of the World. Genders, Globalizations, Transnational Times. Sage.

Jón Baldvin Hannibalsson (2016). „Mannréttindabarátta í 100 ár“", www.jbh.is/prenta.asp?id=381, downloaded 23.11. 2016.

Laufey Valdimarsdóttir (1929). A Brief History of the Woman Suffrage Movement in Iceland. London: International Alliance of Women for suffrage and Equal Citizenship.

Nye, R.A. (2005). “Locating masculinity: Some recent work on men”, Signs 3(30), 1937-1962.

Offen, K. (2000). European Feminisms 1700-1950. A Political History. Stanford: Stanford University Press.

Painter, N. I. (2010). The History of White People. New York: W.W. Norton \& Company.

Sigríður Dúna Kristmundsdóttir (1997). Doing and Becoming. Women's Movements and Women's Personhood in Iceland 1870 - 1990. Reykjavík: Social Science Research Institute, University Press - University of Iceland.

Sigríður Dúna Kristmundsdóttir (1998). „Móðir, kona, meyja: Um fortíðina í nútímanum og stöðu kvenna“ in G.J. Guðmundsson and E.K. Björnsson (eds.) Íslenskea Sögupingið 1997, Rádstefnurit II (p.p. 333-338). Reykjavík: Sagnfræðistofnun Háskóla Íslands, Sagnfræðingafélag Íslands.

Sigrîđur Dúna Kristmundsdóttir (2001). Björg. Ævisaga Bjargar C. Dorláksson. Reykjavík: JPV útgáfa.

Sigríður Dúna Kristmundsdóttir (2006). Ólafía. Ævisaga Ólafiu Jóhannsdóttur. Reykjavík: JPV útgáfa.

Sigríður Th. Erlendsdóttir (1993). Veröld sem ég vil. Saga Kvenréttindafélags Íslands 1907-1912. Reykjavík: Kvenréttindafélag Íslands.

Simkin, J. (2015). „Men’s League for Women’s Suffrage“, in Spartacus-educational, http/spartacus-educational.com/wmen.htm, downloaded 10.9. 2015.

Stjórnarskéa um bin sjerstaklegu málefni Íslands uppfarð með breytingum frá 1903. www.forsaetisraduneytid.is/ media/stjórnarskrá 1903, downloaded 31.5. 2015.

Stjórnarskéa um bin sjerstaklegu málefni Íslands uppfarð með öllum breytingum til og með 1915. www.forsaetisraduneytid.is/media/stjórnarskrá 1915, downloaded 31.5.2015.

porleifur Friðriksson (2007 ). Við brín nýs dags. Saga verkamannfélagsins Dagsbruinar 1906-1930. Reykjavík: Efling, stéttarfélag, Sagnfræðistofnun Háskóla Íslands.

Wollstonecraft, M. (1792). A Vindication of the Rights of Woman: With Strictures on Political and Moral Subjects. Republished e.g. 2014 by Yale University Press.

\section{Papers and journals.}

Austri (1894). "Um rýmkun kosningaréttar til Alpingis", 4(5), 17-18.

Daffari (1906). "Stefnuleysið”, 1(20), 79.

Ingólfur (1909). "Ungmennafélögin”, 7(12), 47.

Ísafold (1902). "Kosningarréttarbreytingin fyrirhugaða", 29(22), 86.

Ísafold (1911). "Ræða Einars Hjörleifssonar skálds á kjósendafundi Sjálfstæðismanna 24. okt. 1911", $38(62), 262$.

Djódólfur (1907). “Almennur kosningaréttur”, 59(32), 1 